\title{
TREATMENT OF DIABETIC KETOACIDOSIS WITH SMALL DOSES OF INSULIN
}

\author{
Major J. H. JOHNSTON, M.B., M.R.C.P., R.A.M.C. \\ Colonel A. T. COOK, M.B., F.R.C.P., F.R.C.P.(Ed.), Late R.A.M.C. \\ British Military Hospital, Rinteln
}

SUMMARY: Seven episodes of diabetic ketoacidosis in five patients were treated during a twelve month period in the British Military Hospital, Rinteln. Hourly injections of small doses of insulin were given with appropriate intravenous fluids, and all patients responded satisfactorily without complications.

The method is a safe and effective form of treatment, offering advantages over the conventional methods, and is recommended for the management of this condition in military hospitals.

\section{Introduction}

Diabetic Ketoacidosis is still a dangerous complication of diabetes mellitus. The criteria for the diagnosis used by different authors vary, but clinical recognition implies metabolic abnormalities severe enough to require " emergency treatment and obsessional care" (Hockaday and Alberti 1972). Treatment must include the infusion of solutions to correct the deficit of water and electrolytes, and the administration of insulin. Since Root (1945) claimed that mortality was reduced by large doses of insulin, and other authors introduced the concept of insulin resistance in ketoacidosis, it has been customary to give large doses in the early stages of treatment. The doses used were usually well tolerated, perhaps because a large proportion was given intravenously, when insulin has a half life of a few minutes and most is removed from the circulation before it has any metabolic effect. Usually combined with sucutaneous or intramuscular injections, these large doses could produce or accentuate plasma hypokalaemia (Soler et al 1972), hyperlactataemia (Alberti and Hockaday 1972), and late hypoglycaemia.

The determination of plasma insulin has shown that the level in the normal individual after intravenous glucose reaches a peak of only $80 \mu \mathrm{U} / \mathrm{ml}$ (Record et al, 1973).

Sönksen et al 1972, confirmed earlier reports (Christensen and Ørskov 1968) that the maximum rate of glucose transport occurs at circulating insulin concentrations between 20 and $200 \mu \mathrm{U} / \mathrm{ml}$, and found that recovery from ketoacidosis could occur at these levels. They also showed that such concentrations could be achieved by intravenous infusion at a rate of 2 to 12 units per hour, and their results have been confirmed (Page et al 1974, Kidson, Kraegen and Lazarus 1974, Semple, White and Manderson 1974).

Continuous infusion of insulin is logical and has advantages over intermittent dosage, but there are technical difficulties. These are of little practical importance in specially equipped centres, but might be troublesome in a general medical unit.

Low doses of insulin have been given subcutaneously in the past (Zschornack and Haller 1965, Mohwicke, Wappler and Bibergeil 1971, Menzel and Jutzi 1970), usually combined with intravenous insulin. As the half life of subcutaneous insulin at the 
injection site is about 4 hours (Binder 1969), there are obvious disadvantages in using this site for repeated doses, particularly in dehydrated patients with poor tissue perfusion. The half life of intramuscular insulin is about 2 hours (Binder 1969), and use of this route would be expected to accelerate action after injection and reduce the risk of depot formation.

Alberti, Hockaday and Turner (1973) treated 17 patients with intramuscular insulin in low doses. Ten to 20 units were given initially followed by 5 to 10 units hourly until the blood glucose fell below $300 \mathrm{mg} / 100 \mathrm{ml}$ when a sliding scale regime using subcutaneous insulin was instituted. Control of hyperglycaemia and ketoacidosis was rapid and comparable with that achieved in 37 patients treated with the conventional large doses given intravenously and intramuscularly, and complications did not occur.

Moseley (1975) found that a regime employing low doses of intramuscular insulin calculated from body weight was entirely effective in children, was easily and safely administered, and imposed minimum demands on the laboratory.

\section{Patients and methods}

During the last year we have treated five patients, one of them three times, for severe diabetic ketoacidosis, using low doses of insulin. All the patients were females between 13 and 30 years of age. One presented initially in coma, while the other four had a history of insulin dependant diabetes of at least 2 years duration. They all required emergency treatment with intravenous fluids and insulin.

Hyperglycaemia and ketonuria were present in all the patients, and all but one showed the classical signs of ketoacidosis. The exception (Case 3) was a woman of 26, diabetic since childhood, who was admitted at 30 weeks gestation in severe pre-eclampsia. She had not attended the Diabetic Clinic and had not received any antenatal care because she did not know she was pregnant. Treatment of her toxaemia and urgent delivery of a stillborn foetus obscured the manifestations and complicated the management of her ketoacidosis.

Case 4 was treated three times. The first episode was precipitated by gastroenteritis and the second occurred soon after stabilisation and was attributed to a urinary infection. Three months later she was admitted again following influenza, and on this occasion was found to have developed a megaloblastic anaemia which fulfilled the criteria for a diagnosis of pernicious anaemia.

The main features of the seven episodes of ketoacidosis are in Table I.

\section{Treatment}

Fluids. Intravenous normal saline was administered to all the patients as the first priority, the first three litres rapidly. Five per cent dextrose was substituted when the blood sugar fell below $200 \mathrm{mg} / 100 \mathrm{ml}$. Oral fluids were encouraged when the patients could take and retain them.

Insulin. An initial dose of 5 or 10 units or soluble insulin was followed by 5 units hourly until the blood sugar fell to $200 \mathrm{mg} / 100 \mathrm{ml}$, when a sliding scale was introduced. The management of Case 3 was complicated by toxaemia, labour and delivery, but an attempt was made to follow the same principles. The insulin was given subcutaneously to the first two cases, and intramuscularly to the remainder. 
Treatment of Diabetic Ketoacidosis with Small Doses of Insulin

Table I

Clinical findings in 5 patients

\begin{tabular}{|c|c|c|c|c|c|c|c|c|}
\hline \multirow{2}{*}{$\begin{array}{l}\text { Case } \\
\text { and } \\
\text { age }\end{array}$} & \multirow{2}{*}{$\begin{array}{c}\text { Daily } \\
\text { insulin } \\
\text { before } \\
\text { admission } \\
\text { (units) }\end{array}$} & \multirow{2}{*}{$\begin{array}{l}\text { Precipit- } \\
\text { ating } \\
\text { factor }\end{array}$} & \multirow{2}{*}{$\begin{array}{l}\text { Clinical } \\
\text { features }\end{array}$} & \multirow{2}{*}{$\begin{array}{l}\text { Duration of } \\
\text { ketoacidosis } \\
\text { before } \\
\text { admission } \\
\text { (hours) }\end{array}$} & \multicolumn{4}{|c|}{ Laboratory findings } \\
\hline & & & & & $\underset{(\mathrm{mg} / 100 \mathrm{ml}}{\text { Glucose }}$ & $\begin{array}{c}\mathrm{Na} \\
(\mathrm{mEq} / 1)\end{array}$ & $\underset{(\mathrm{mEq} / 1)}{\mathrm{K}}$ & $\begin{array}{r}\mathrm{HCO}_{\mathrm{g}} \\
(\mathrm{mEq} / 1)\end{array}$ \\
\hline $\begin{array}{c}1 \\
\text { Age } 23\end{array}$ & $48-64$ & Pregnancy & $\begin{array}{l}\text { Conscious } \\
\text { vomiting } \\
\text { dehydrated } \\
\text { air hunger }\end{array}$ & 12 & 360 & 139 & 5.2 & 8 \\
\hline $\begin{array}{c}2 \\
\text { Age } 13\end{array}$ & 32 & NK & As above & 48 & 630 & - & 5.3 & 6.6 \\
\hline $\begin{array}{c}3 \\
\text { Age } 26\end{array}$ & 20 & $\begin{array}{l}\text { P.E.T. } \\
\text { labour }\end{array}$ & $\begin{array}{l}\text { Drowsy } \\
\text { oedema } \\
\text { hypertension }\end{array}$ & NK & 420 & 126 & 5.1 & 9.5 \\
\hline $\begin{array}{c}4 a \\
\text { Age } 30\end{array}$ & 56 & $\begin{array}{l}\text { Gastro- } \\
\text { enteritis }\end{array}$ & $\begin{array}{l}\text { Conscious } \\
\text { vomiting } \\
\text { dehydrated } \\
\text { air hunger }\end{array}$ & 48 & 520 & 136 & 4.8 & 4.4 \\
\hline $\begin{array}{c}4 b \\
\text { Age } 30\end{array}$ & 60 & $\begin{array}{l}\text { Urinary } \\
\text { infection }\end{array}$ & As above & 4 & 530 & 129 & 4.2 & 9.5 \\
\hline $\begin{array}{c}4 c \\
\text { Age } 30\end{array}$ & 56 & $\begin{array}{l}\text { Influenza } \\
\text { P.A. }\end{array}$ & As above & 12 & 520 & 134 & 5.2 & 7.7 \\
\hline$\stackrel{5}{\text { Age } 20}$ & $\begin{array}{l}\text { Undiag- } \\
\text { nosed }\end{array}$ & NK & $\begin{array}{l}\text { Comatose } \\
\text { dehydrated } \\
\text { air hunger }\end{array}$ & NK & 688 & 142 & 6.6 & 4.0 \\
\hline
\end{tabular}

Potassium. $13 \mathrm{mEg}$ of potassium chloride were added to at least one litre of intravenous fluid. Subsequent additions were made only if indicated by the serum potassium levels. Oral potassium was given when feeding was resumed.

Antibiotics and other supportive measures were used when necessary. Bicarbonate was not given to any of the patients, which may have helped to reduce significant hypokalaemia (Soler et al 1973).

\section{Results of treatment}

These are summarised in Table II. All the patients responded satisfactorily. Dehydration was corrected, the signs of acidosis subsided, nausea and vomiting stopped, the level of consciousness rose in those in whom it was impaired, and the blood glucose fell to normal levels. There were no episodes of hypoglycaemia, and hypokalaemia occurred in only two patients, in one of whom it was relatively minor.

\section{Discussion}

On the basis of his experience, Alberti (1974) provided a simple guide to the management of diabetic ketoacidosis using small doses of insulin. This contrasts with the diverse regimes previously recommended. Although we have not followed his scheme in every 
Table II

Treatment of 5 cases

\begin{tabular}{|c|c|c|c|c|c|c|c|c|}
\hline \multirow[b]{2}{*}{ Case } & \multirow[b]{2}{*}{$\begin{array}{l}\text { Route of } \\
\text { insulin } \\
\text { admini- } \\
\text { stration }\end{array}$} & \multirow{2}{*}{$\begin{array}{l}\text { Insulin } \\
\text { dosage } \\
\text { (units) }\end{array}$} & \multicolumn{3}{|c|}{ IV therapy in first 24 hours } & \multirow[b]{2}{*}{$\begin{array}{l}\text { Rate of fall } \\
\text { of blood } \\
\text { glucose } \\
\text { (per cent) }\end{array}$} & \multirow[b]{2}{*}{$\begin{array}{l}\text { Time for } \\
\text { glucose to } \\
\text { fall to } 200 \\
\mathrm{mg} / 100 \mathrm{ml}\end{array}$} & \multirow[b]{2}{*}{$\begin{array}{c}\text { Lowest } \\
\mathbf{K}+ \\
(\mathrm{mEq} / 1)\end{array}$} \\
\hline & & & $\begin{array}{l}\text { N saline } \\
\text { (litres) }\end{array}$ & $\begin{array}{c}5 \text { per cent } \\
\text { Dextrose } \\
\text { (litres) }\end{array}$ & $\underset{(\mathrm{mEq})}{\mathrm{K}+}$ & & & \\
\hline 1 & $\mathrm{SC}$ & $\begin{array}{l}10 \text { stat. } \\
5 \text { hourly } \\
\text { (total } 35 \text { ) }\end{array}$ & 5 & 1 & 13 & $\begin{array}{l}61 \text { after } \\
4 \text { hours }\end{array}$ & 4 hours & 4.4 \\
\hline 2 & SC & $\begin{array}{l}10 \text { stat. } \\
5 \text { hourly } \\
\text { (total } 40 \text { ) }\end{array}$ & 4 & 3 & 52 & $\begin{array}{l}54 \text { after } \\
2 \text { hours }\end{array}$ & 6 hours & 3.5 \\
\hline 3 & $\mathbf{I M}$ & $\begin{array}{l}20 \text { stat. } 10 \\
3 \text { hours later } \\
5 \text { hourly } \\
\text { (total } 55 \text { ) }\end{array}$ & 4 & 1 & 13 & $\begin{array}{l}26 \text { after } \\
5 \text { hours }\end{array}$ & 9 hours & 4.2 \\
\hline $4 a$ & IM & $\begin{array}{l}5 \text { hourly } \\
\text { (total } 40 \text { ) }\end{array}$ & 3 & 2 & 13 & $\begin{array}{l}49 \text { after } \\
5 \text { hours }\end{array}$ & 8 hours & 3.4 \\
\hline $4 b$ & IM & $\begin{array}{l}5 \text { hourly } \\
\text { (total 20) }\end{array}$ & 3 & 3 & 13 & $\begin{array}{l}66 \text { after } \\
3 \text { hours }\end{array}$ & 3 hours & 4.2 \\
\hline $4 c$ & IM & $\begin{array}{l}10 \text { stat. } \\
5 \text { hourly } \\
\text { (total 30) }\end{array}$ & 5 & 1 & 13 & $\begin{array}{l}79 \text { after } \\
5 \text { hours }\end{array}$ & 5 hours & 4.0 \\
\hline 5 & IM & $\begin{array}{l}10 \text { stat. } \\
5 \text { hourly } \\
\text { (total } 50 \text { ) }\end{array}$ & 6 & 3 & 91 & $\begin{array}{l}18 \text { after } \\
2 \text { hours }\end{array}$ & 9 hours & 2.7 \\
\hline
\end{tabular}

detail, we have found the method effective and safe. We are impressed by the ease of administration, the reduced demands on staff and equipment, and the absence of complications. Recovery of these patients was at least as rapid as with the large doses of insulin used previously, and the transfer to routine treatment after control of ketoacidosis is a smoother and simpler process.

Although our two patients treated with subcutaneous insulin did as well as the others, the theoretical advantage lies with the intramuscular route, and we have adopted this as routine.

\section{Conclusion}

The use of small doses of intramuscular insulin in the treatment of diabetic ketoacidosis has advantage over the former conventional methods, and is particularly suitable for the general medical unit of a military hospital.

\section{Acknowledgement}

We thank Major G. O. Cowan, M.B., M.R.C.P., R.A.M.C. for permission to report patients who were under his care. 


\section{REFERENCES}

Alberti, K. G. M. M. and Hockaday, T. D. R. (1972). Diabetes 21, (Suppl. 1, 350).

Alberti, K. G. M. M., Hockaday, T. D. R. and Turner, R. C. (1973). Lancet ii, 515.

Alberti, K. G. M. M. (1974). Symposium on Advanced Medicine 10. Pitman Medical. London. P.68. Binder, C. (1969). Absorption of Injected Insulin. Copenhagen.

Christensen, N. J. and Ørskov. H. (1968). J. clin. Invest. 47, 1262.

Hockaday, T. D. R. and AlberTi, K. G. M. M. (1972). Brit. J. Hosp. Med. 7, 183.

Kidson, W., Casey, J., Kraegen, E. and Lazarus, L. (1974). Brit. med. J. ii, 691.

Menzel, R. and JutZI, E. (1970). Disch. Gesundh.-Wes. 25, 727.

MohWICKe, G., WAPPLER, E. and BiBERGEIL, H. (1971). Handbuch des Diabetes Mellitus ii, 1121. Lehmans Verlag. Munich.

MOSELEY, J. (1975). Brit. med. J. i, 59.

Page, M.McB., Alberti, K. G. M. M., Greenwood, R. GumaA, K. A., Hockaday, T. D. R., Lowy, C., Nabarro, J. D. M., Pyke, D. A. Sönksen, P. H., Watkins, P. J. and West, T. E. T. (1974). Brit. med. J. ii, 687.

Record, C. O., Alberti, K. G. M. M., Williamson, D. H. and Wright, R. (1973). Clin. Sci. 45, 677. Root, H. F. (1945). J. Amer. med. Ass. 127, 557.

Semple, P. F., White, C. and MANDerson, W. G. (1974). Brit. med. J. ii, 694.

Soler, N. G., Bennett, M. A., Dixon, K. Fitzgerald, M. G. and Malins, J. M. (1973). Lancet i, 951.

Sönksen, P. H., Ellis, J. P., Lowy, C., Rutherford, A. and Nabarro, J. D. N. (1965). Diabetologia 1, 208.

Sönksen, P. H., Srivastava, M. C., Tompkins, C. V. and Nabarro, J. D. N. (1972). Lancet ii, 155.

ZsChornaCK, M. R. and HALleR, H. (1965). Med. Klin. 60, 1508. 